\title{
The Effect of Anaerobic Co-Substrate on Removal of COD, Phenol and Methane Production in Coal Gasification Wastewater Treatment
}

\author{
Yajie Li, ${ }^{1,2}$ Lingyu Liu, Qingshui Wang1, Jiazi Wu', Tonghui Liu', \\ Yaoliang Hong ${ }^{1}$, Wenru Liu' ${ }^{1}$, Juan Mei ${ }^{1 *}$ \\ ${ }^{1}$ School of Environmental Science and Engineering, Jiangsu Provincial Key Laboratory of Environmental Science \\ and Engineering, Suzhou University of Science and Technology, Suzhou 215009, China \\ ${ }^{2}$ Jiangsu Key Laboratory of Anaerobic Biotechnology, School of Environment and Civil Engineering, \\ Jiangnan University, Wuxi 214122, China
}

Received: 7 February 2020

Accepted: 9 April 2020

\begin{abstract}
In this paper, potato starch wastewater (PSW) was adopted as anaerobic co-substrate added in influent of coal gasification wastewater (CGW). The control anaerobic biofilters (AF) and supplemented AF were investigated in our research. Without co-digestion, both of the COD and total phenol removal rates were only $30 \%$, respectively. However, adding PSW (COD $=1000 \mathrm{mg} / \mathrm{L}$ ) as co-substrate meanwhile increasing concentration of CGW in influent step by step from phase 1 to phase 3 . In phase 1 and 2, the effluent COD and total phenol reached $1000 \mathrm{mg} / \mathrm{L}$ and $50 \mathrm{mg} / \mathrm{L}$, respectively. Further increasing COD of PSW to $1500 \mathrm{mg} / \mathrm{L}$ in phase 4, the removal rates of COD and total phenol almost reached $50 \%$, respectively. The methane production rate was increased to $260 \mathrm{mLCH}_{4} / \mathrm{gCOD} / \mathrm{d}$. In order to further improve the treatment efficiency in co-digestion, the two-stage AFs were adopted in our next study, the result indicated that with adding PSW $(\mathrm{COD}=1500 \mathrm{mg} / \mathrm{L})$ in the first stage AF (R1) and extending the HRT of R1 to $48 \mathrm{~h}$, both of the total removal rates of COD and total phenol almost reached $75 \%$, respectively, meanwhile methane production rate of the second AF (R2) rising to $300 \mathrm{mLCH}_{4} / \mathrm{gCOD} / \mathrm{d}$ in phase 4 .
\end{abstract}

Keywords: coal gasification wastewater, co-digestion, anaerobic biofilters, two-stage anaerobic biofilters

\section{Introduction}

Coal chemical industry is a very promising industry in China and coal gasification is known as the leading

*e-mail: susie_mei@163.com technology in the new coal chemical industry. However the increasing control of pollutant emission by the state is undoubtedly a challenge for the coal chemical industry, which has huge consumption and huge wastewater output [1]. The coal gasification wastewater (CGW) contains many complex, toxic and refractory pollutants such as phenolics, heterocyclics, ammonia 
and sulfide [2-4]. Although through solvent extraction and steam stripping pretreatment, phenols and ammonia can be partly removed, some high concentrations pollutants still existed in effluent [5-8]. Because of the low biodegradability of the $\mathrm{CGW}$ which leads to great difficulties to the biological treatment.

Anaerobic biological technologies are characterized by cost-effective and high efficiency in disposing refractory organic substances and could enhance the biodegradability of wastewater [9-11]. There are many anaerobic bioreactors adopted in CGW treatment, such as external circulation anaerobic reactor (ECAR) [12], anaerobic granular activated carbon (GAC) bioreactors, the expanded-bed GAC reactor, and the hybrid UASB reactor [13], AnaEG (anaerobic expanded granular sludge bed) [14]. Among them, AF (anaerobic biofilters) is widely applied in refractory wastewater because start-up time is short, no sludge reflux and additional sludge separation equipment is needed, the effluent SS (suspended solid) is low, and the operation and management are convenient [15]. However, How to alleviate the toxicity of $\mathrm{CGW}$ and improve CGW treatment efficiency in AF is a bottleneck of CGW anaerobic treatment. Anaerobic co-digestion technology has been widely used in the treatment of industrial wastewater [16]. Because it is difficult for anaerobic bacteria to directly utilize the refractory substances as carbon source or energy, However, when other easily utilized carbon sources or energy exist in influent, the refractory pollutants could be degraded efficiently in the system, There are some substances added in the CGW as co-substrate in CGW such as methanol [10], glucose wastewater [14]. Potato starch wastewater (PSW) as easily biodegradable substrate is an economic product in coal gasification industry. Hence, it is feasible to enhance the anaerobic biodegradability of CGW as a co-substrate [16]. However, finding the suitable concentration is the key to improve the degradation rate of COD, phenol and methane production in CGW treatment.

Because the conventional single anaerobic process could not get a better performance for the CGW treatment efficiency. Hence it is logically thinking that the two stage anaerobic reactors might get the better result in treating the refractory wastewater than a single reactor. Moreover, the two stage anaerobic reactors can prolong hydraulic retention time (HRT).
Meanwhile, adding co-substrate in the first stage anaerobic reactor is benefit for the organics and refractory organic compounds biodegradation. Thus, optimizing the operation of the two stage anaerobic reactors to continuously carry out co-digestion of easily biodegradable organics and refractory organic compounds could be the key to the success of the technology on the anaerobic treatment of real CGW [17].

The arms of this study were to explore the AF treating CGW with adding PSW as co-substrate and the process efficiency in comparison with the control $\mathrm{AF}$ and supplemented AF were investigated. The quick start-up AF under co-digestion conditions and the treatment efficiency of further increasing concentrations of PSW $(\mathrm{COD}=1500 \mathrm{mg} / \mathrm{L})$ in AF system were discussed. In addition, two stages AFs in co-digestion strategy applied in treat CGW were studied.

\section{Material and Methods}

\section{Anaerobic Biofilter Reactor}

The AFs were filled with soft filter and made of cylindrical plexiglass. The influent was pumped into the bottom of the reactor and effluent flowed out from the top. One of the AF (called the supplemented AF) was operated by adding PSW as co-substrate. The other $\mathrm{AF}$ (called the control AF) was operated without adding PSW. The effective volume of the supplemented reactor and the control reactor were $2 \mathrm{~L}$ and $3.9 \mathrm{~L}$, respectively. Both the two reactors were operated at temperatures of $35^{\circ} \mathrm{C}$. The biogas produced in the reactors was pretreated by $3 \mathrm{M} \mathrm{NaOH}$ absorption and then collected by a gas collection tank. The volume of $\mathrm{CH}_{4}$ was monitored through gas flow meter.

The effective volume of the two stage AFs were R1 $($ reactor 1$)=3.9 \mathrm{~L}$ and R2 (reactor 2) $=2 \mathrm{~L}$, respectively. The HRT of R1 and R2 depended on the operation need.

\section{Inoculated Sludge}

The inoculated anaerobic activated sludge was taken from an expanded granular sludge bed (EGSB) treating starch wastewater. The inoculation volume was $30 \%$ of the effective volume of reactor. The suspended solids

Table 1. Characteristics of the coal gasification wastewater.

\begin{tabular}{|c|c|c|c|c|c|}
\hline Parameter & Scale $(\mathrm{mg} / \mathrm{L})$ & Average value $(\mathrm{mg} / \mathrm{L})$ & Parameter & Scale $(\mathrm{mg} / \mathrm{L})$ & Average value $(\mathrm{mg} / \mathrm{L})$ \\
\hline $\mathrm{COD}$ & $1500-2800$ & 2500 & $\mathrm{pH}$ & $6.8-8.9$ & 7.2 \\
\hline $\mathrm{BOD}_{5}$ & $10-24$ & 13.5 & $\mathrm{TC}$ & $720-850$ & 830 \\
\hline Total phenol & $200-400$ & 320 & $\mathrm{IC}$ & $90-150$ & 120 \\
\hline $\mathrm{NH}_{4}^{+}-\mathrm{N}$ & $180-260$ & 230 & TOC & $650-760$ & 730 \\
\hline
\end{tabular}

$\mathrm{NH}_{4}^{+}$-N: ammonia nitrogen; TC: total carbon; TOC: total organic carbon; IC: inorganic carbon 
(SS) and volatile suspended solids (VSS) in the reactor were about 8.3 and $4.8 \mathrm{~g} / \mathrm{L}$, respectively.

\section{Coal Gasification Wastewater}

Coal gasification wastewater (CGW) was taken from Harbin Coal Chemical Industry Co, Ltd in China, and it was pretreated by phenol extraction and ammonia stripping. The characteristic of CGW in the research was shown in Table 1.

\section{Potato Starch Wastewater}

The PSW was artificially taken by grinding potatoes using grinding machine meanwhile a little sulfate was also added in. The concentration of PSW was depended on the demands of the research.

\section{Analytical Methods}

$\mathrm{COD}, \mathrm{BOD}_{5}, \mathrm{NH}_{4}^{+}-\mathrm{N}, \mathrm{pH}$ and MLSS were measured according to the standard procedures [18]. TOC, IC and TC were monitored by the total organic carbon analyzer (Japan, Shimadzu TOC-LCSH). The volume of biogas production was determined by wet glass flowmeter, and methane content was analyzed through a $3 \mathrm{M} \mathrm{NaOH}$ solution. The concentrations of total phenols were measured by the titration method [19].

\section{Result and Discussion}

\section{The Start-Up of AF Treating CGW without Co-substrate}

As shown in Fig. 1, a constant HRT of the control AF was $48 \mathrm{~h}$ and the concentrations of effluent COD and total phenol fluctuated with influent COD and total phenol. The average influent COD and total phenol were about 2592 and $311 \mathrm{mg} / \mathrm{L}$, respectively. The effluent COD and total phenol reached 1827 and $215 \mathrm{mg} / \mathrm{L}$ and both removal rates were only $30 \%$, respectively.

\section{The Start-Up of AF treating CGW with Adding PSW as Co-Substrate}

Adding PSW as co-substrate, the operation conditionwas listed in Table 2, As shown in Fig. 2a), the HRT of AF was $48 \mathrm{~h}$, in order to successfully start-up the AF, the CGW was diluted for 4 times in phase 1 , meanwhile adding PSW $(\mathrm{COD}=1000 \mathrm{mg} / \mathrm{L})$ in the influent, the effluent COD was kept about $750 \mathrm{mg} / \mathrm{L}$ and the removal rate of COD was a little fluctuating but more than $50 \%$. In phase 2 , increasing the organic load in influent and the CGW was diluted for 2 times meanwhile kept PSW (COD $=1000 \mathrm{mg} / \mathrm{L})$ adding in influent, the effluent COD was about $1000 \mathrm{mg} / \mathrm{L}$. In phase 3, adding PSW $(C O D=1000 \mathrm{mg} / \mathrm{L})$ in influent
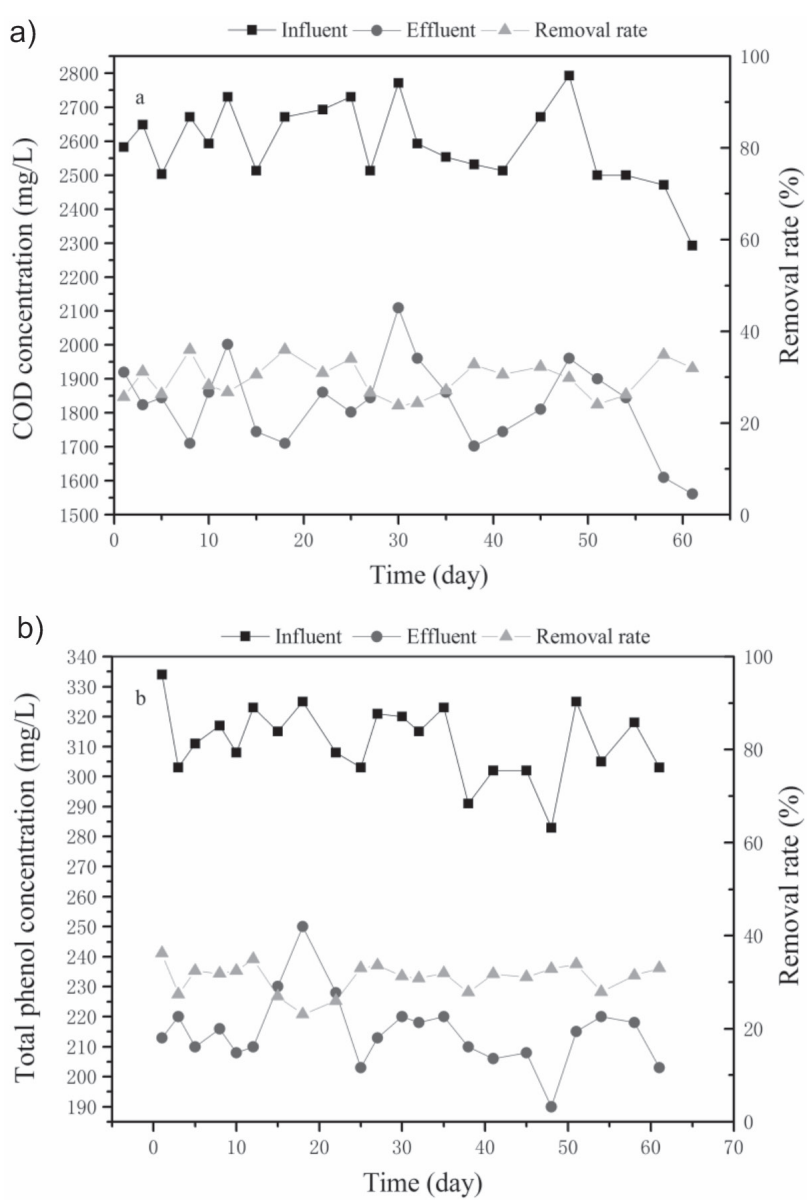

Fig. 1. Performance of the control AF. a) The removal of COD in control AF; b) The removal of total phenol in control AF.

and the CGW without dilution, the effluent COD was increasing to $1500 \mathrm{mg} / \mathrm{L}$.

As shown in Fig. 2b), in order to have an adaptive process for anaerobic microorganism in the system. In phase 1 , kept the influent total phenol was about $55 \mathrm{mg} / \mathrm{L}$ and the effluent total phenol was stably reached $25 \mathrm{mg} / \mathrm{L}$, In phase 2, increasing the influent total phenol

Table 2. Operational condition in AF treating CGW under PSW as co-substrate.

\begin{tabular}{|c|c|c|c|c|}
\hline $\begin{array}{c}\text { Phase } \\
(\text { day })\end{array}$ & $\begin{array}{c}\text { COD } \\
(\mathrm{mg} / \mathrm{L})\end{array}$ & $\begin{array}{c}\text { PSW } \\
(\mathrm{mg} \text { COD/L })\end{array}$ & $\begin{array}{c}\text { Total phenol } \\
(\mathrm{mg} / \mathrm{L})\end{array}$ & $\begin{array}{c}\text { HRT } \\
(\mathrm{h})\end{array}$ \\
\hline $\begin{array}{c}\text { Phase } 1 \\
(0-30)\end{array}$ & 1480 & 1000 & 55 & 48 \\
\hline $\begin{array}{c}\text { Phase 2 } \\
(30-60)\end{array}$ & 2100 & 1000 & 135 & 48 \\
\hline $\begin{array}{c}\text { Phase 3 } \\
(60-90)\end{array}$ & 3500 & 1000 & 315 & 48 \\
\hline $\begin{array}{c}\text { Phase } 4 \\
(0-30)\end{array}$ & 4000 & 1500 & 315 & 48 \\
\hline
\end{tabular}

Phase 1: 4 times dilution of CGW+PSW $(\mathrm{COD}=1000 \mathrm{mg} / \mathrm{L})$ Phase 2: 2 times dilution of $\mathrm{CGW}+\mathrm{PSW}(\mathrm{COD}=1000 \mathrm{mg} / \mathrm{L})$

Phase 3: $\mathrm{CGW}+\mathrm{PSW}(\mathrm{COD}=1000 \mathrm{mg} / \mathrm{L})$

Phase 4: $\mathrm{CGW}+\mathrm{PSW}(\mathrm{COD}=1500 \mathrm{mg} / \mathrm{L})$ 
a) $\quad \longrightarrow$ influent $\longrightarrow$ effluent $-\Delta-$ removal rate

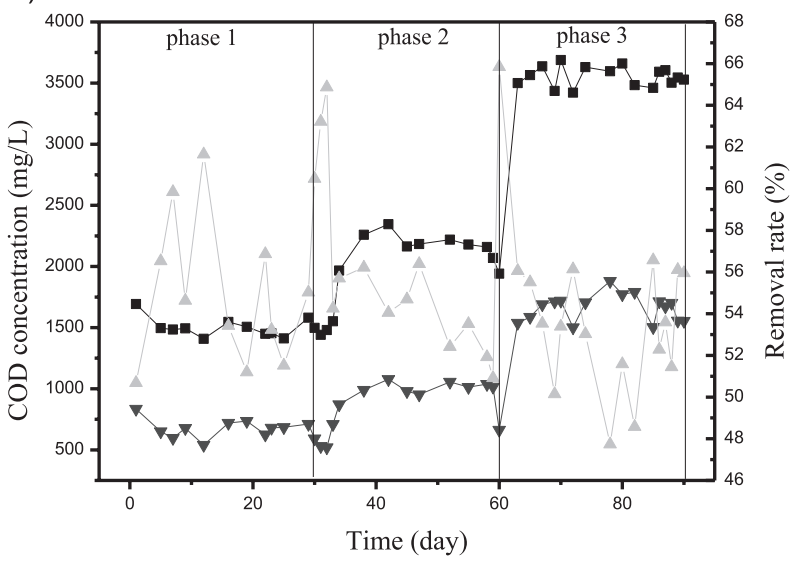

b)

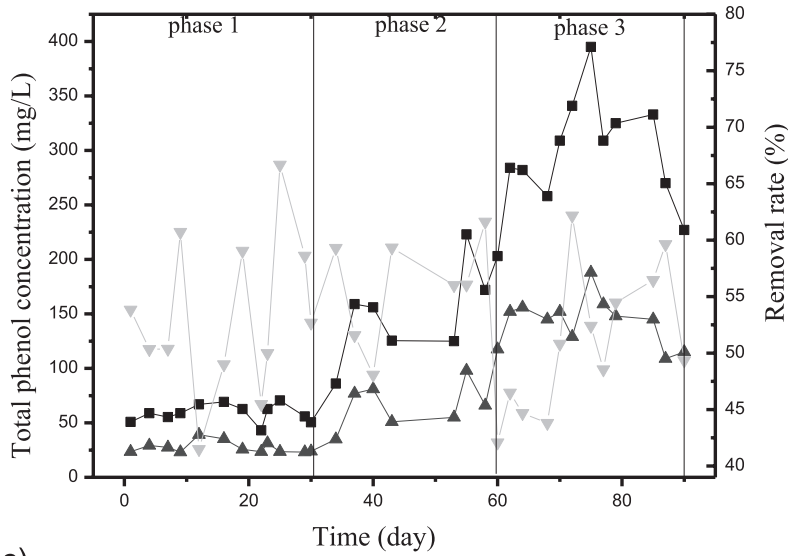

c)

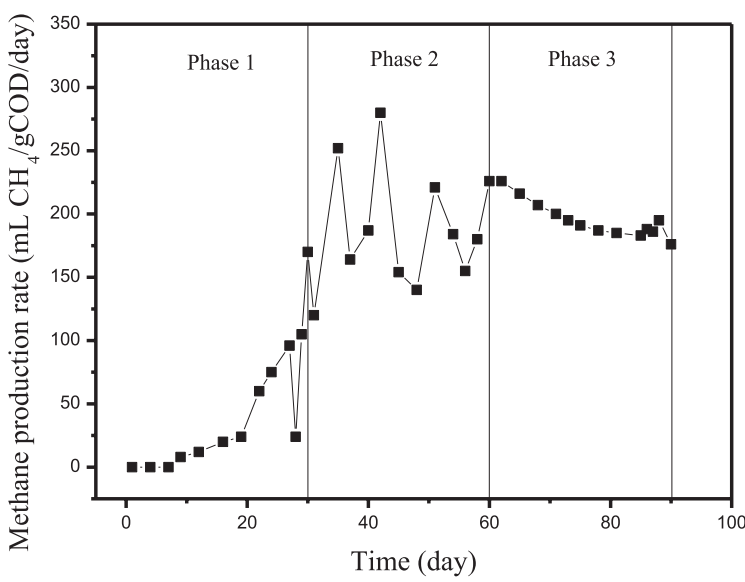

Fig. 2. AF treating CGW with PSW (COD $=1500 \mathrm{mg} / \mathrm{L})$ as co-substrate. a) The removal of COD; b)The removal of total phenol; c) Methane production rate.

to $135 \mathrm{mg} / \mathrm{L}$, the effluent total phenol was kept about $50 \mathrm{mg} / \mathrm{L}$, both of the removal rates in phase 1 and 2 were over $48 \%$ respectively and the system was in stability. However, in the phase 3 the CGW without dilution, the effluent total phenol concentration fluctuated greatly and the removal rate was unstable.

In the co-digestion conditions, the methane production rate in the system as shown in Fig. 2c), when adopted step-feed mode, it produced most rapid biomass acclimation and development. The methane was produced after one week. Moreover, the refractory substances in the system were degraded to some extent because co-substrate can induce the required enzymes of metabolism and generate enough energy to drive the initial transformation of the toxic matters, alleviate the inhibition of methanogens [16]. Hence, the methane production rate rose gradually in fluctuation in phase 1 and 2 . In phase 3 , with the increasing concentrations of pollutants in the system, the inhibitory effect on methanogens was gradually enhanced which led to methane production rate declined slightly. Hence, in co-digestion conditions, AF indicated good and stable treatment efficiency. However, further enhancing the concentration of $\mathrm{CGW}$ in influent, the removal of COD and total phenol showed the unsatisfied results. Zhang [20] has investigated the dynamic model of cometabolism and made a conclusion that the concentration of growth matrix determined the synthesis of key enzymes in the process of co-metabolism, meanwhile the concentration has an optimal value. The induction and promotion of the synthesis of key enzymes is mainly by increasing the proportion of the growth matrix during the reaction process. Hence, the strategy of increasing the concentration of PSW in influent was adopted in the next operation.

\section{Increasing Concentration of Co-Substrate in AF Treating CGW}

As shown on the Table 2, when increasing the concentration of PSW to COD $=1500 \mathrm{mg} / \mathrm{L}$, in phase 4, the effluent COD was about $1500 \mathrm{mg} / \mathrm{L}$, compared with phase 3, Although the organic load in influent was increased, the effluent COD changed little. It was indicated AF system has strong resistance to organic load. Compared with phase 3 , the concentration of effluent total phenol was decreased and the methane production rate was obviously increased from $200 \mathrm{~mL}$ $\mathrm{CH}_{4} / \mathrm{gCOD} / \mathrm{d}$ in phase 3 to $260 \mathrm{~mL} \mathrm{CH}_{4} / \mathrm{gCOD} / \mathrm{d}$ in phase 4 . Because increasing the concentration of PSW in the system, which provided more microbial carbon or energy, enhanced the microbial synergy metabolism, improved the system of the activity of hydrolytic acidification bacteria especially phenol degradation bacteria which is advantageous to phenol degradation or conversion in anaerobic condition. As shown in Fig. 3c), the AF was running continuously from phase 1 to phase 4 and suddenly increasing a small amount of organic load in influent in phase 4 which can stimulate the growth of methanogens. Hence, the methane production rate can increase to more than $280 \mathrm{~mL} / \mathrm{gCOD} /$ day. Then the following few days, the increased influent organic load maybe exceeded the degradation capacity of the acid-producing bacteria in the system, hence the methane production rate fell slightly in a short time, and finally stabilized at $260 \mathrm{~mL} / \mathrm{gCOD} /$ day which still exceeded the methane production rate of the phase 3 .

On the contrary, when adding insufficient cosubstrate, the key enzymes produced by microbe were 


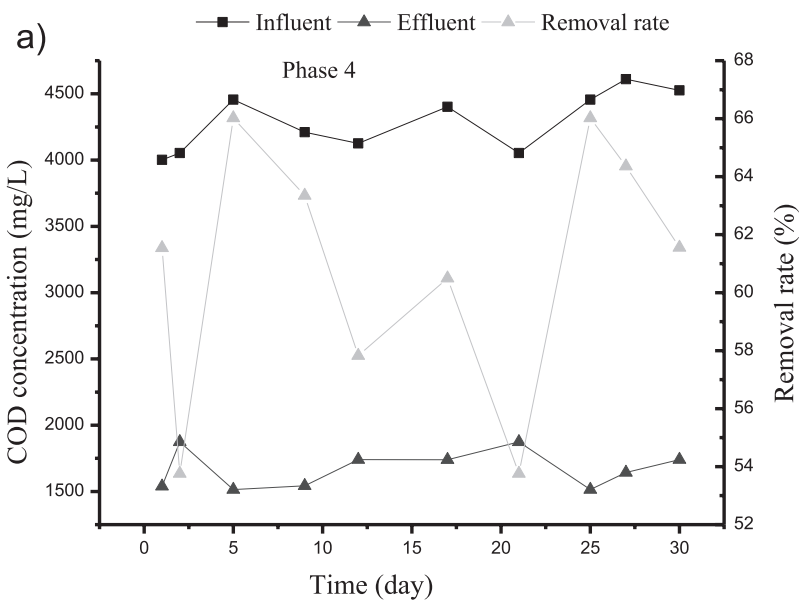

b) $\rightarrow$ Influent $\longrightarrow$ Effluent $-\triangle-$ Removal rate

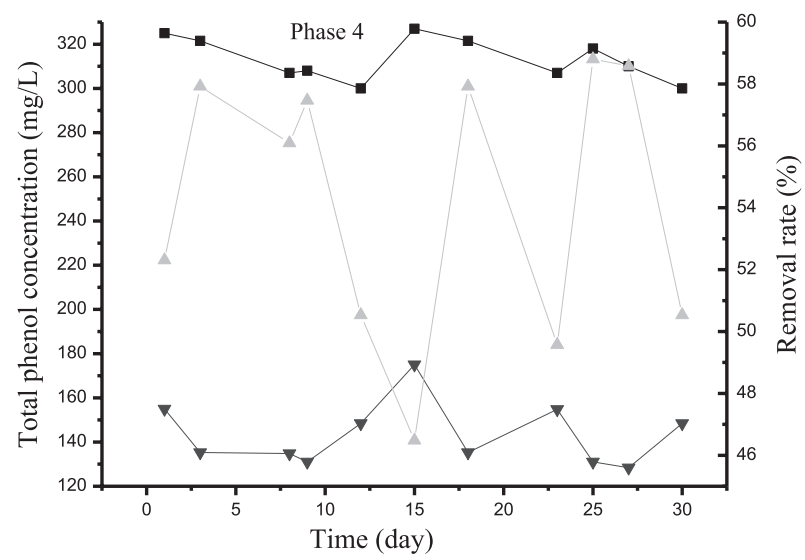

c)

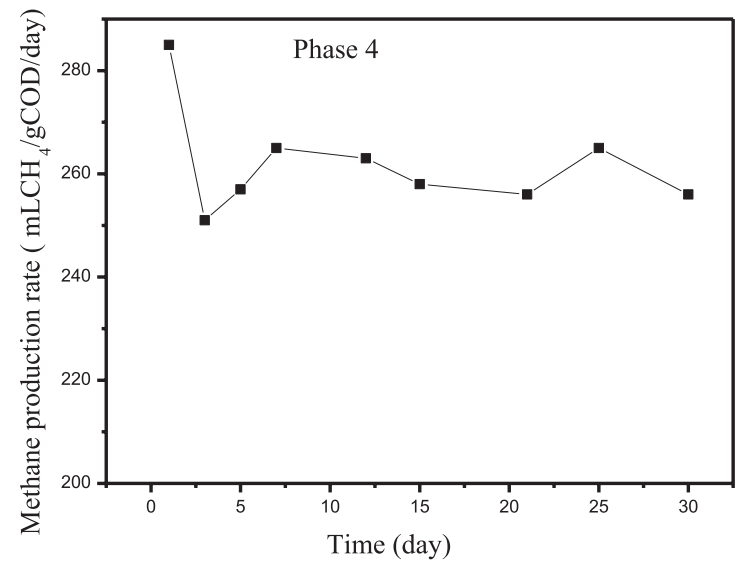

Fig. 3. AF treating CGW with PSW $(\mathrm{COD}=1500 \mathrm{mg} / \mathrm{L})$ as cosubstrate. a)The removal of COD; b)The removal of total phenol; c) Methane production rate.

Table 3. The operation condition of two stage AFs treating coal gasification wastewater.

\begin{tabular}{|c|c|c|c|c|c|c|c|c|}
\hline $\begin{array}{c}\text { Phase } \\
\text { (day ) }\end{array}$ & \multicolumn{2}{|c|}{$\begin{array}{c}\text { Phase 1 } \\
0-15\end{array}$} & \multicolumn{2}{c|}{$\begin{array}{c}\text { Phase 2 } \\
15-30\end{array}$} & \multicolumn{2}{c|}{$\begin{array}{c}\text { Phase 3 } \\
30-45\end{array}$} & \multicolumn{2}{c|}{$\begin{array}{c}\text { Phase 4 } \\
45-60\end{array}$} \\
\hline $\begin{array}{c}\text { HRT } \\
\text { (h) }\end{array}$ & R1 & R2 & R1 & R2 & R1 & R2 & R1 & R2 \\
18 & 48 & 24 & 48 & 36 & 48 & 48 & 48 \\
\hline
\end{tabular}

Adding the PSW $(\mathrm{COD}=1500 \mathrm{mg} / \mathrm{L})$ as co-substrate in influent in all phases in R1.
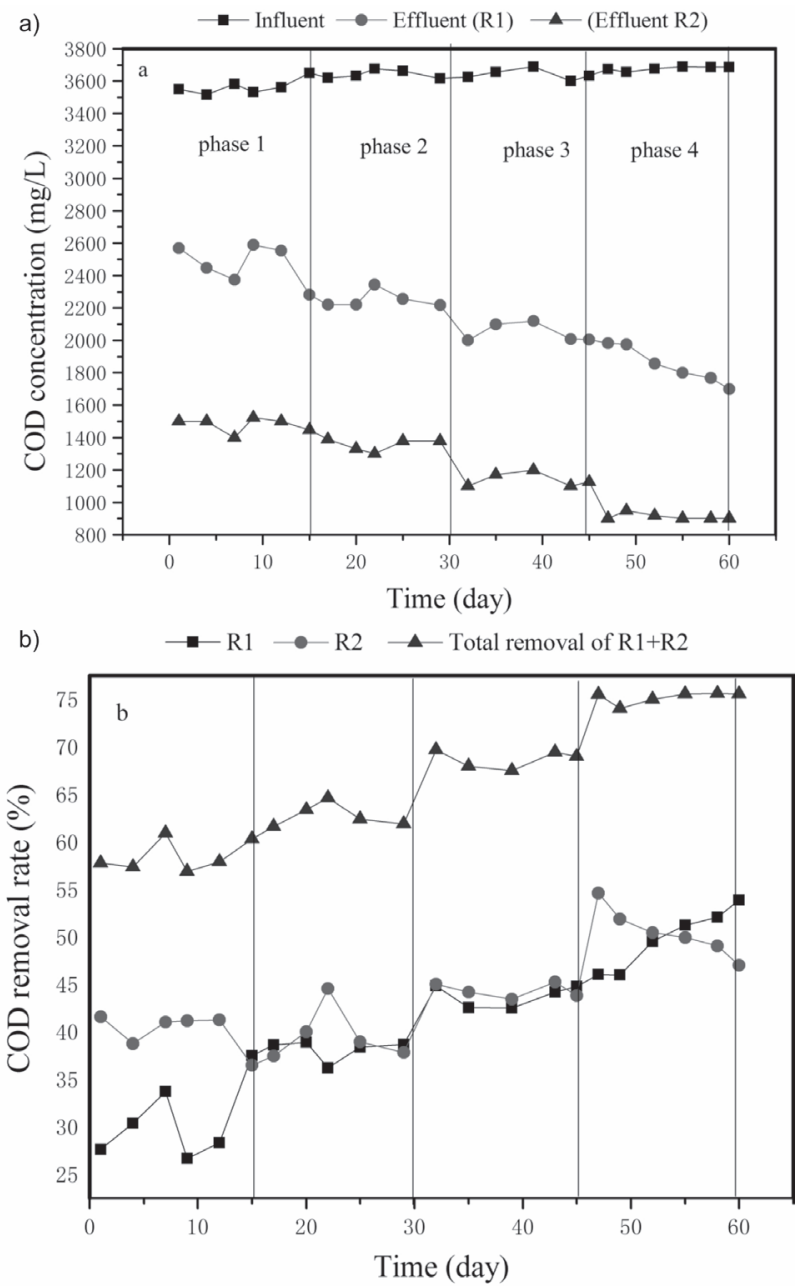

Fig. 4. COD removal of two stage AFs treating CGW with PSW $(\mathrm{COD}=1500 \mathrm{mg} / \mathrm{L})$ as co-substrate. a) Variation of influent and effluent COD;(b) COD removal rate.

also reduced correspondingly. Hence, the growth and reproduction of the microorganism lack enough carbon and energy resource, the degradation demand of non-growth matrix cannot be fully satisfied and it could not be degraded efficiently for CGW. Consequently, the refractory pollutants could be accumulated in the system. According to the law of tolerance [21], if the non-growth substrate was in excess in quality or quantity, which is close to or achieve metabolic microbial tolerance limit, the organic pollutants will affect this kind of bacterial biological activity.

\section{The Two-Stage AFs Treating CGW under Co-digestion Conditions}

In order to further improve the biodegradation performance and the methane production rate of CGW, the operation of two stage AFs treating CGW was investigated on the basis of co-digestion. The operation condition of the reactors was shown in Table 3. Adding the PSW $(\mathrm{COD}=1500 \mathrm{mg} / \mathrm{L})$ as co-substrate in influent 
a)
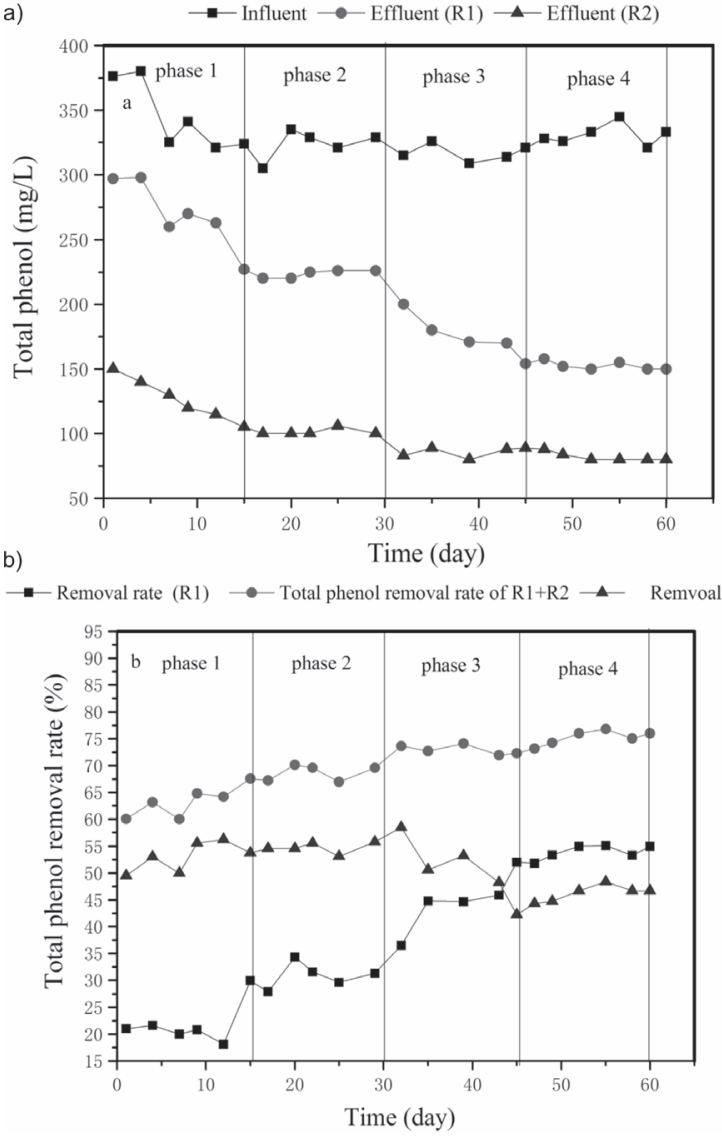

Fig. 5. Total phenol removal of two stage AFs treating CGW with $\mathrm{PSW}(\mathrm{COD}=1500 \mathrm{mg} / \mathrm{L})$ as co-substrate. a) Variation of influent and effluent total phenol; b) Total phenol removal rate.

in all phases in R1 (reactor 1) and the HRT of R1 were $18 \mathrm{~h}, 24 \mathrm{~h}, 36 \mathrm{~h}, 48 \mathrm{~h}$ from phase 1 to 4, respectively. Meanwhile kept the HRT $=48 \mathrm{~h}$ in all phases in R2 (reactor 2). As shown in Fig. 4a), with the extending of HRT in R1 in phase 4, the effluent COD of R1 and R2 were decreased to 1800 and $900 \mathrm{mg} / \mathrm{L}$, respectively. And the total COD removal rate of $\mathrm{R} 1+\mathrm{R} 2$ reached $75 \%$. The result indicated that although adding co-substrate in influent, the HRT of phase 1 was short which led to unsatisfied performance with COD removal rate only $30 \%$ in $\mathrm{R} 1$. In phase 3 and 4 , the COD removal rate of $\mathrm{R} 1$ reached $53 \%$ and the $\mathrm{COD}$ removal rate of $\mathrm{R} 2$ was fluctuated with that of R1, Hence, the HRT was an important factor in co-digestion process.

The total phenol removal of $\mathrm{R} 1$ was shown in Fig. 5, with the prolonging of HRT, the removal rate was enhanced from $21 \%$ to $55 \%$, the result indicated that the biodegradation of phenol-degradating bacteria was greatly improved after long time acclimation. Moreover, in phase 4, the total phenol removal rate in R2 was a little decreased compared with R1, because of most of the phenol and monophenol with hypotoxicity and simple chemical structure. Hence, it can be degraded easily in R1. On the contrary, because of the complicated chemical structure and high toxicity, the

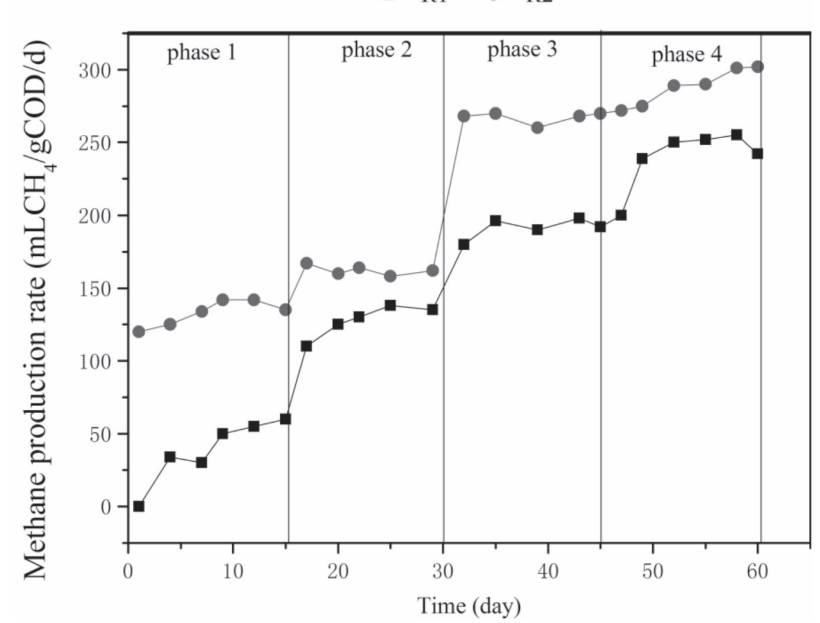

Fig. 6. Methane production rate of two stage AFs treating CGW with PSW $(\mathrm{COD}=1500 \mathrm{mg} / \mathrm{L})$ as co-substrate.

left polyphenol was difficult to be biodegraded easily or non-degraded under co-digestion conditions even further prolonging HRT in the system.

The methane production rate as shown in Fig. 6, In R1 and R2, the methane production rate was increased step by step which indicated that on the one hand, adding PSW in the system can benefit for the degradation or transformation of organic pollutants. On the other hand, the organic pollutants treated by two stage AFs and gradually extending HRT can be better for hydrolysis and acidification. Hence, it can bring better performance of methane production rate and in $\mathrm{R} 2$ the methane production rate reached almost $300 \mathrm{mLCH}_{4} / \mathrm{gCOD} / \mathrm{d}$ in phase 4 .

\section{Conclusions}

Without co-digestion, the effluent COD and total phenol reached 1827 and $215 \mathrm{mg} / \mathrm{L}$, respectively. With the both removal rates only $30 \%$. When adding PSW $(\mathrm{COD}=1000 \mathrm{mg} / \mathrm{L})$ as co-substrate and CGW was stepfeed in $\mathrm{AF}$, the effluent COD and total phenol reached $1000 \mathrm{mg} / \mathrm{L}$ and $50 \mathrm{mg} / \mathrm{L}$ in phase 1 and 2, respectively. However, adding CGW without dilution in phase 3, the treatment efficiency was unsatisfied. When increasing COD of PSW to $1500 \mathrm{mg} / \mathrm{L}$, the removal rates of COD and total phenol almost reached 50\%, respectively. The methane production rate was increasing to $260 \mathrm{mLCH}_{4} / \mathrm{gCOD} / \mathrm{d}$ in phase 4 . In order to further improve the treatment efficiency of $\mathrm{CGW}$, the two stage AFs were adopted in our next research, the result indicated that with adding PSW (COD $=1500 \mathrm{mg} / \mathrm{L})$ under co-digestion conditions, extending the HRT of R1 to $48 \mathrm{~h}$, both of the total removal rates of COD and total phenol almost enhanced to $75 \%$, respectively and methane production rate of $\mathrm{R} 2$ was increasing to $300 \mathrm{mLCH}_{4} / \mathrm{gCOD} / \mathrm{d}$ in phase 4 . 


\section{Acknowledgements}

The present study was supported by the Jiangsu Provincial Key Laboratory of Environmental Science and Engineering (No. Zd1903), the Suzhou City Science and Technology Project (SNG2018049), Natural Science Foundation of Jiangsu Higher Education(19KJB610024), the Open Research Fund Program of Jiangsu key laboratory of anaerobic biotechnology (JKLAB201704), Youth Fund of Suzhou University of Science and Technology (XKQ2018001).

\section{Conflict of Interest}

The authors declare no conflict of interest.

\section{References}

1. ZHUANG H.F., HAN H.J., MA W.C., HOU B.L., JIA S.Y., ZHAO Q. Advanced treatment of biologically pretreated coal gasification wastewater by a novel heterogeneous Fenton oxidation process. Journal of environmental sciences, 33, 12, 2015.

2. HOU B.L., HAN H.J., JIA S.Y., ZHUANG H.F., ZHAO Q., XU P. Effect of alkalinity on nitrite accumulation in treatment of coal chemical industry wastewater using moving bed biofilm reactor. Journal of environmental sciences, 26, 1014, 2014.

3. WANG W., HAN H.J. Recovery strategies for tackling the impact of phenolic compounds in a UASB reactor treating coal gasification wastewater. Bioresource Technology, 103, 95, 2012.

4. GAI H.J., SONG H.B., XIAO M., FENG Y.R., WU Y.M., ZHOU H., CHEN B.H. Conceptual design of a modified phenol and ammonia recovery process for the treatment of coal gasification wastewater. Chemical Engineering Journal, 304, 621, 2016.

5. LI P., AILIJIANG N., CAO X.X., LEI T., LIANG P., ZHANG X.Y., HUANG X., TENG J.L. Pretreatment of coal gasification wastewater by adsorption using activated carbons and activated coke. Colloids and Surfaces A-Physicochemical and Engineering Aspects, 482, 177, 2015.

6. ZHAO Q., HAN H.J., XU C.Y., ZHUANG H.F., FANG F., ZHANG L.H. Effect of powdered activated carbon technology on short-cut nitrogen removal for coal gasification wastewater. Bioresource Technology, 142, 179, 2013.

7. XU P., HAN H.J., ZHUANG H.F., HOU B.L., JIA S.Y., XU C.Y., WANG D.X. Advanced treatment of biologically pretreated coal gasification wastewater by a novel integration of heterogeneous Fenton oxidation and biological process. Bioresource Technology, 182, 389, 2015.

8. FENG Y.Y., SONG H.B., XIAO M., LIN K.Q., GUO K., GAI H.J. Development of phenols recovery process from coal gasification wastewater with mesityl oxide as a novel extractant. Journal of cleaner production, 166, 1314, 2017.

9. JI Q.H., TABASSUMA S., YU G.X., CHU C.F., ZHANG Z.J. Determination of biological removal of recalcitrant organic contaminants in coal gasification waste water. Environmental Technology, 36, 2815, 2015.

10. WANG W., HAN H.J., YUAN M., LI H.Q. Enhanced anaerobic biodegradability of real coal gasification wastewater with methanol addition. Journal of environmental sciences, 22, 1868, 2010.

11. ARAFATH K. A. Y., GOPINATH S., NILAVUNESAN D., SIVANESAN S., BASKARALINGAM. P. Phenol degradation and chemical oxygen demand analysis of coir retting wastewater using anaerobic treatment. Journal of Environmental Biology, 40, 784, 2019.

12. JIA S.Y., HAN H.J., ZHUANG H.F., HOU B.L., LI $\mathrm{K}$. Impact of high external circulation ratio on the performance of anaerobic reactor treating coal gasification wastewater under thermophilic condition. Bioresource Technology, 192, 507, 2015.

13. WANG W., MA W.C., HAN H.J., LI H.Q., YUAN M. Thermophilic anaerobic digestion of Lurgi coal gasification wastewater in a UASB reactor. Bioresource Technology, 102, 2441, 2011.

14. LI C.J., TABASSUM S., ZHANG Z.J. An advanced anaerobic expanded granular sludge bed (AnaEG) for the treatment of coal gasification wastewater. RSC advance, $\mathbf{4}$, 57580, 2014.

15. LI Y.J., TABASSUM S., CHU C.F., ZHANG Z.J. Inhibitory effect of high phenol concentration in treating coal gasification wastewater in anaerobic biofilter. Journal of Environmental Sciences, 64, 207, 2018.

16. LI Y.J., TABASSUM S., YU Z.J., WU X.G., ZHANG X.J., SONG Y.P., CHU C.F., ZHANG Z.J. Effect of effluent recirculation rate on the performance of anaerobic biofilter treating coal gasification wastewater under codigestion conditions. RSC advance, 6, 87926, 2016.

17. WANG W., HAN H.J., YUAN M., LI H.Q., FANG F., WANG K. Treatment of coal gasification wastewater by a two-continuous UASB system with step-feed for COD and phenols removal. Bioresource Technology, 102, 5454, 2011.

18. C.E.P.B. Standard Methods for Water and Wastewater Analysis, $4^{\text {th }}$ ed.; China Environmental Science Press: Beijing, China, 67-69, 2002.

19. MAKRIGIANNI V., GIANNAKAS A., DELIGIANNAKIS Y., KONSTANTINOU I. Adsorption of phenol and methylene blue from aqueous solutions by pyrolytic tire char: Equilibrium and kinetic studies. Journal of Environmental Chemical Engineering, 3, 582, 2015.

20. ZHANG X.H., BAJPAI R. The establishment of a common metabolic model based on the key enzyme-a case study of trichloroethylene with methane bacteria. Journal of Environmental Sciences, 20, 558, 2000.

21. HU J.C., ZHOU M.J., ZUO J.W., ZHOU Q., HE M. Technology and theory of anaerobic biological treatment of wastewater, $1^{\text {st }}$ ed.; China Construction Industry Press: Beijing, China, 64-68, 2002. 